\title{
NOTA
}

\section{MITOCHONDRIAL DNA VARIATION OF THE DENGUE'S MOSQUITO VECTOR Aedes aegypti (Diptera: Culicidae) IN RIVERA CITY, NORTHERN URUGUAY}

\author{
Arley Camargo1, Deibi González² \& Nancy Suárez² \\ ${ }^{1}$ Centro Universitario de Rivera, Universidad de la República, Ituzaingó 667, Rivera 40000, Uruguay. \\ 2Unidad de Epidemiología, Dirección Departamental de Salud, Ministerio de Salud Pública, Insausti 1090, \\ Rivera 40000, Uruguay.
}

*Corresponding author: arley.camargo@gmail.com

\begin{abstract}
The mosquito Aedes aegypti is the main vector of the dengue virus. We collected 14 individuals from Rivera City, northern Uruguay, to sequence the mitochondrial ND4 gene. The two haplotypes found in Rivera also cooccur in Argentina and Brazil, supporting several potential routes of colonization of northern Uruguay.
\end{abstract}

Keywords: ND4 gene, haplotype network, phylogeography

\section{RESUMEN}

Variación del ADN mitocondrial del mosquito vector del dengue Aedes aegypti (Diptera: Culicidae) en la Ciudad de Rivera, norte de Uruguay. El mosquito Aedes aegypti es el principal vector del virus del dengue. Secuenciamos el gen mitocondrial ND4 de 14 individuos colectados en Rivera, norte de Uruguay. Los dos haplotipos encontrados en Rivera también se encuentran en Argentina y Brasil, apoyando distintas vías de colonización del norte de Uruguay.

Palabras clave: gen ND4, red de haplotipos, filogeografía

The yellow fever mosquito Aedes aegypti is the main vector of several arboviruses in tropical and subtropical regions worldwide, including the dengue virus, the most common, widespread, and of major concern because of its re-emergence in temperate areas and the current lack of an effective vaccine (Bowman et al., 2016). Aedes aegypti originated in sub-Saharan Africa from a forest-dwelling ancestor that fed on non-human animals. Subsequently, after the Sahara aridification, the mosquito went through a process of domestication in urban settings providing stable water and food (human blood) supplies, and becoming an invasive species that spread rapidly to the New World via ship transportation during the European colonization (Powell \& Tabachnick, 2013). After several dengue and yellow fever epidemics in the Americas during the 19th century and the first half of the 20th century, there were a number of eradicationre-infestation cycles of $A$ e. aegypti that resulted in a geographic distribution similar to the pre-eradication era (Soper, 1963; Basso, 2010). In Uruguay, the mosquito reappeared in 1997 after the latest eradication in 1958, and dispersed from eastern and northern regions limiting with Argentina and Brazil, respectively, until reaching most of the country in 2007 (Basso, 2010).

Since 1996, the Ministry of Public Health (MPH) of Uruguay carries out a nationwide surveillance program to check for the presence of Aedes larvae and pupae in households of major urban centers (Basso, 2010). Based on a morphological taxonomic key (Rossi \& Martínez, 2013), Aedes larvae and pupae can be identified, but there is no full discrimination between Ae. aegypti and Ae. albopictus as they cannot be distinguished with this key. In 2014 and 2015, a number of samples collected in the city of Rivera, northern Uruguay, were used in genetic analyses after positive identification by the local epidemiology unit of the $\mathrm{MPH}$. Herein, we investigated the evolutionary affinities of these specimens based on comparison of DNA sequences with publicly available records. Our goals were threefold: (a) to confirm the taxonomic identity of these samples as Ae. aegypti, (b) to characterize the genetic variation of our sample in order to assign them to the known Ae. aegypti mtDNA lineages, (c) to evaluate potential routes of dispersal of the mosquito to northern Uruguay based on phylogeographic patterns.

We selected 14 specimens representative of 11 sampling points throughout Rivera city (Table 1). Tissues were stored in $95 \%$ ethanol and were processed with the Quick-gDNA MiniPrep kit (Zymo Research) to extract whole genomic DNA after digestion with proteinase $\mathrm{K}$ at $56^{\circ} \mathrm{C}$. Next, we amplified a fragment of the mitochondrial ND4 gene via PCR using the primers ND4F and ND4R, and the temperature profile of Bracco et al. (2007) in a Arktik thermal cycler (Thermo Scientific). After amplification, PCR products were visualized with UV light after an electrophoretic run in a $0.7 \%$ agarose gel stained with GoodView (SBS Genetech). Amplicons were purified with GeneJET PCR Purification kit (Thermo Fisher Scentific) 
Table 1. Sampling locations (street), sample size, and collection date of Aedes aegypti in Rivera. City, Uruguay. Haplotype numbers correspond to those used in Fig. 1.

Location (N)

$\begin{array}{lc}\text { Figueroa (2) } & 29 \text { May } 2014 \\ \text { Cuaró (1) } & 5 \text { May } 2014 \\ \text { Aristegui (1) } & 29 \text { July } 2014 \\ \text { Ortega (1) } & 7 \text { May } 2014 \\ \text { Ibarborou (2) } & 5 \text { May } 2014 \\ \text { Cementerio (2) } & 5 \text { May } 2015 \\ \text { Berreta (1) } & 14 \text { July } 2015 \\ \text { Ugón (1) } & 16 \text { July } 2015 \\ \text { Lavalleja (1) } & 12 \text { June } 2015 \\ \text { Rincón (1) } & 14 \text { July } 2015 \\ \text { de Mello (1) } & 14 \text { July } 2015\end{array}$

Coordinates

$-30.89080 \mathrm{~S}, \quad-55.55217 \mathrm{~W}$

11,22

$-30.88829 \mathrm{~S}, \quad-55.55297 \mathrm{~W}$

11

$-30.88883 \mathrm{~S}, \quad-55.55585 \mathrm{~W}$

$-30.90458 \mathrm{~S}, \quad-55.54754 \mathrm{~W}$

22

$-30.89080 \mathrm{~S}, \quad-55.55217 \mathrm{~W}$

11

$-30.91167 \mathrm{~S}, \quad-55.53750 \mathrm{~W}$

11

$-30.52861 \mathrm{~S}, \quad-55.33194 \mathrm{~W}$

11

$-30.54074 \mathrm{~S}, \quad-55.32956 \mathrm{~W}$

11

$-30.54413 \mathrm{~S}, \quad-55.32215 \mathrm{~W}$

11

$-30.54727 \mathrm{~S}, \quad-55.32429 \mathrm{~W}$

11

$-30.53033 \mathrm{~S}, \quad-55.33285 \mathrm{~W}$ and sent to Macrogen (www.macrogen.com) for dideoxy Sanger sequencing. Nucleotide sequences were checked by inspecting chromatograms in Geneious 8.1.6 (Biomatters Ltd.), and aligned with ND4 sequences downloaded from GenBank (www.ncbi.nlm.nih.gov) using ClustalX (Larkin et al., 2007). We also downloaded and included in the alignment the sequences of several Aedes species: Ae. albopictus, Ae. mettalicus, Ae. luteocephalus, Ae. longipalpis, Ae. vittatus, and Ae. unilineatus (see Appendix for full list of accession numbers and the complete alignment). Sequences were collapsed into unique haplotypes to estimate a haplotype network using the function haploNet in the R package 'pegas', which is based on distances obtained from an infinite site model of evolution (Paradis, 2010).

We sequenced 269 base pairs of the ND4 gene for all 14 samples from Rivera and found two haplotypes (GenBank accession numbers: MF947532 in 12 individuals and MF947533 in two individuals). From GenBank, we downloaded 628 ND4 sequences of $A e$. aegypti (search on Oct 18, 2018), and one sequence for each of the outgroup species, except for $A e$. albopictus, which was represented with four sequences. When collapsing the full alignment of 651 sequences into 172 haplotypes, we found that the most frequent haplotype in Rivera is also very common in the Americas and in other continents (haplotype 11 in the network, see Fig. 1), as it occurs in the following countries: Myanmar, Cameroon, Ivory Coast, Senegal, Nigeria, Guinea, USA (Arizona), Mexico, Colombia, Ecuador, Bolivia, and Brazil. The less frequent haplotype in Rivera has a more limited distribution in the Americas (haplotype 22 in the network, see Fig. 1), including Colombia, Argentina, and several states of Brazil (São Paulo, Maranhão, and Paraná). The haplotype network shows that the two haplotypes from Rivera are nested within the Ae. aegypti clade (see Fig. 1), further confirming that our samples were correctly identified as Ae. aegypti. Indeed, Ae. albopictus, which cannot be distinguished from $A e$. aegypti based on larval morphology alone, is several mutational steps away from any Ae. aegypti haplotype, which highlights the use of ND4 sequence data as a basis for species discrimination.

Our results confirmed that the larva and pupa collected in Rivera were correctly identified as Ae. aegypti using taxonomic keys of larval-stage characters (Rossi \& Martínez, 2013). In addition, the two haplotypes found are common worldwide (haplotype 11) or in the Americas (haplotype 22). However, the limited records available from southern South America, and the wide distribution of these haplotypes do not allow discarding several potential routes of colonization. While a large number of records for both haplotypes are available from Brazil, and particularly from the southern State of Paraná, there is one record from Argentina that shares haplotype 22 with Uruguay. Therefore, limited sampling of ND4 sequences in Argentina makes difficult to ascertain the geographic origin of the lineages present in northern Uruguay. On the other hand, there is a relatively good sampling of ND5 sequences in Argentina, but this gene has not been used as frequently as ND4 as a marker worldwide, and particularly in Brazil, based on GenBank 


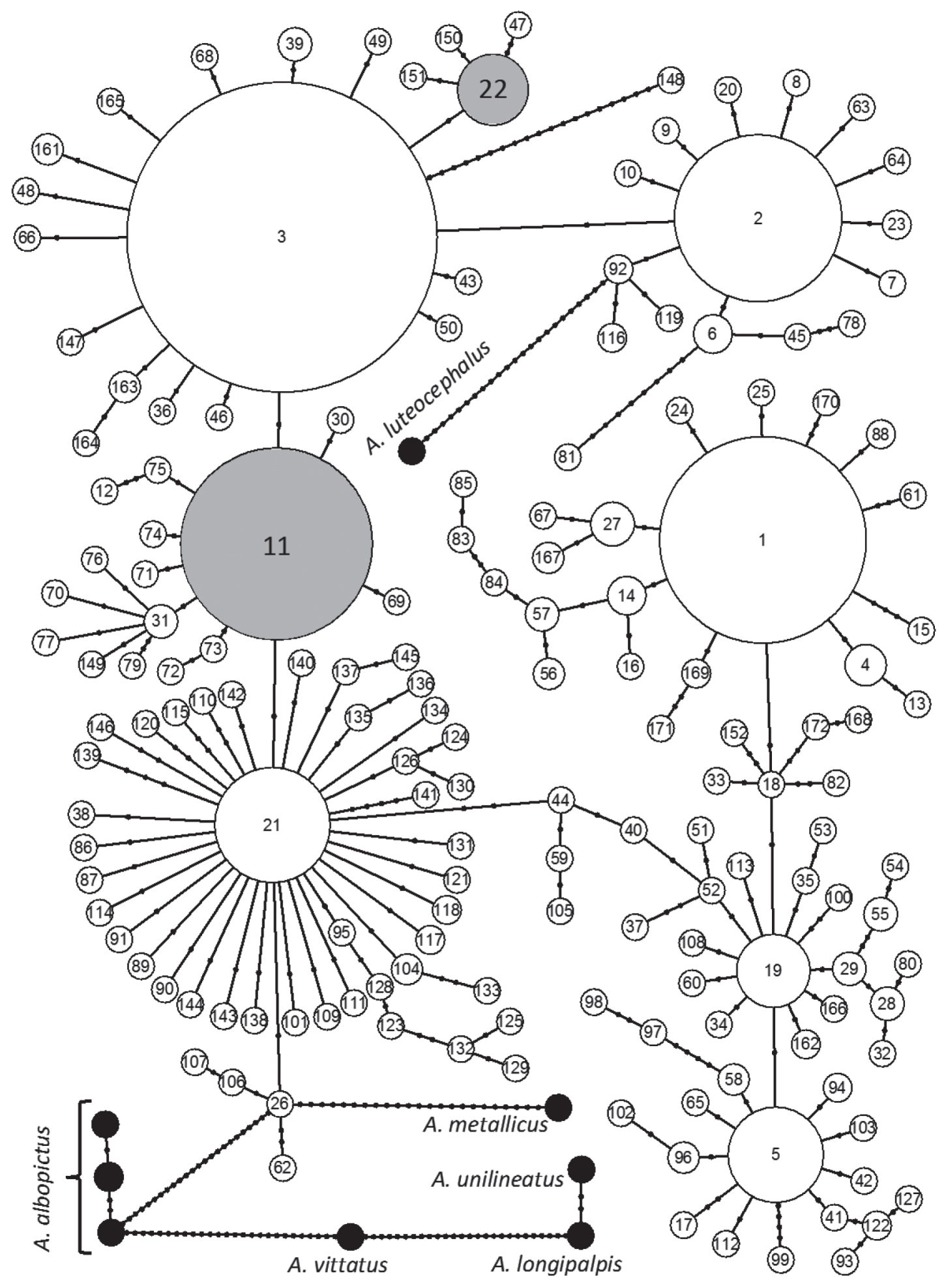

Fig. 1. Haplotype network of 651 ND4 sequences of Ae. aegypti and other Aedes species. Size of haplotypes is proportional to their frequency. All Ae. aegypti haplotypes are numbered. Outgroup haplotypes are shown in black and labeled with the species names. Dots along lines connecting haplotypes represent mutational steps. Haplotypes 11 and 22 found in Rivera are shown in gray. 
records. Independently of the specific origin of each lineage found in Rivera, the relatively high frequency of these haplotypes in the region and worldwide suggests that their occurrence in this part of the country is the result of rapid population expansion from neighboring countries.

There have been two previous population genetic studies of $A e$. aegypti that included samples from Uruguay (Pereira, 2010; Soliani et al., 2010). Based on RAPD and microsatellite data, Pereira (2010) found two main clusters: one in western Uruguay (Salto, Fray Bentos, and Mercedes), and another one in the northeast (Rivera and Treinta y Tres). In addition, the samples from western Uruguay were more similar to an Argentinean sample (Buenos Aires) than with the northeastern region, suggesting that two separate colonization events from distinct sources occurred in Uruguay. This result is consistent with our findings that the population in Rivera might have been originated from colonization from southern Brazil, while populations from western Uruguay would have originated from neighboring Argentina. Soliani et al. (2010) used ISSR markers and sample the same populations in Uruguay (except Rivera) and several Argentinean populations. They found that western Uruguay was probably colonized from neighboring cities in Argentina via human transportation using the international bridges across the Uruguay River. The Treinta y Tres population from the east appeared similar to Mercedes and Fray Bentos from the west, but these populations had an important contribution from a source that not represented in any of the Argentinean populations (except for the neighboring city of Gualeguaychú). Again, this result suggests that there is an additional source, probably originated from Brazil that has colonized the northeast and other parts of Uruguay.

We suggest that additional sampling from neighboring Brazilian states (e.g., Rio Grande do Sul and Santa Catarina) and Argentina, and the sequencing of both ND4 and ND5 genes, will be necessary to completely resolve the composition, the geographic origin, and the colonization routes of the Ae. aegypti lineages present in Uruguay. Within Uruguay, it will be ideal to expand sampling to include localities throughout the country, particularly in the southern and western portions (Montevideo, Canelones, and Salto), places where an outbreak of autochthonous dengue took place in the austral summer of 2016 after 100 years without incidents (www.who.int/csr/don/10-march-2016-dengueuruguay). A better understanding of lineage composition in Uruguayan populations might provide useful guidance in control strategies of this vector given that resistance to insecticides (Bisset et al., 2013) and susceptibility to infection by the dengue virus (Sim et al., 2013) appear to vary between Ae. aegypti strains. In addition, the screening of more hypervariable markers such as microsatellites will also be necessary to shed light on the connectivity patterns among populations and to predict the potential spread of dengue and other viruses transmitted by this vector.

We thank two reviewers for helpful comments and edits that improved an earlier version of the manuscript.

\section{APPENDIX}

DNA sequence alignment in TreeBASE repository: https://www.treebase.org/treebase-web/search/study/ summary.html?id=23606

\section{REFERENCES}

Basso C. 2010. Aedes aegypti, principal transmisor de la enfermedad del dengue. En: Basso C. (Ed.) Abordaje ecosistémico para prevenir y controlar al vector del dengue en Uruguay, pp.15-58. Universidad de la República, Montevideo.

Bisset J.A., Marín R., Rodríguez M.M., Severson D.W., Ricardo Y., French L., Díaz M. \& O. Pérez. 2013. Insecticide resistance in two Aedes aegypti (Diptera: Culicidae) strains from Costa Rica. Journal of Medical Entomology, 50: 352361.

Bowman L.R., Donegan S. \& P.J. McCall. 2016. Is dengue vector control deficient in effectiveness or evidence? Systematic review and metaanalysis. PLoS Neglected Tropical Diseases, 10:e0004551.

Bracco J.E., Capurro M.L., Lourenço-de-Oliveira R. \& M.A. Mureb Sallum. 2007. Genetic variability of Aedes aegypti in the Americas using a mitochondrial gene: evidence of multiple introductions. Memórias do Instituto Oswaldo Cruz, 102: 573-580.

Larkin M.A., Blackshields G., Brown N.P., Chenna R., McGettigan P.A., McWilliam H., Valentin F., Wallace I.M., Wilm A., Lopez R., Thompson J.D., Gibson T.J. \& D.G. Higgins. 2007. Clustal $W$ and Clustal $X$ version 2.0. Bioinformatics, 23: 2947-2948.

Paradis E. 2010. pegas: an R package for population genetics with an integrated-modular approach. Bioinformatics, 26: 419-420.

Pereira J. 2010. Genética de Poblaciones como herramienta de apoyo a estudios epidemiológicos. En: Basso C. (Ed.) Abordaje ecosistémico para prevenir y controlar al vector del dengue en Uruguay, pp. 169-182. Universidad de la República, Montevideo.

Powell J.R. \& W.J. Tabachnick. 2013. History of domestication and spread of Aedes aegypti - A review. Memórias do Instituto Oswaldo Cruz, 
108(Suppl 1):11-17.

Rossi G.C. \& M. Martínez. 2013. Lista de especies y clave ilustrada para la identificación de larvas de mosquitos (Diptera: Culicidae) halladas criando en recipientes artificiales en Uruguay. Boletín de la Sociedad Zoológica del Uruguay (2da. época), 22: 49-65.

Sim S., Jupatanakul N., Ramirez J.L., Kang S., RomeroVivas C.M., Mohammed H. \& G. Dimopoulos. 2013. Transcriptomic profiling of diverse Aedes aegypti strains reveals increased basal-level immune activation in dengue virus-refractory populations. PLoS Neglected Tropical Diseases, 7:e2295.
Soliani C., Ronda-Dueñas J., Chiappero M.B., Martínez M., García Da Rosa E. \& C.N. Gardenal. 2010. Genetic relationships among populations of Aedes aegypti from Uruguay and northeastern Argentina inferred from ISSR-PCR data. Medical and Veterinary Entomology, 24: 316-323.

Soper F.L. 1963. The elimination of urban yellow fever in the Americas through the eradication of Aedes aegypti. American Journal of Public Health \& Nation's Health, 53: 7-16.

Fecha de Recepción: 19 de diciembre de 2018 Fecha de Aceptación: 26 de mayo de 2019 